\title{
Supporting students to succeed in open and distance learning in the Open University of Sri Lanka and Universitas Terbuka Indonesia
}

Supporting students to succeed in ODL

\author{
Aminudin Zuhairi \\ Faculty of Teacher Training and Education, \\ Universitas Terbuka, Tangerang Selatan, Indonesia, and \\ Navaratnasamy Karthikeyan and Saman Thushara Priyadarshana \\ The Open University of Sri Lanka, Colombo, Sri Lanka
}

\begin{abstract}
Purpose - The purpose of this paper is to reveal how support services for open and distance students are designed, developed and implemented to ensure successful learning to take place, with specific references to the Open University of Sri Lanka (OUSL) and Universitas Terbuka (UT) Indonesia. Success in distance learning is one major challenge for open universities to respond to expectations of students and stakeholders. This study focuses on the strategies of student support services in OUSL and UT, investigating related factors including instructional design and development, learning engagement and motivation, policy and strategy in reducing dropouts, use of OER/MOOCs, and quality assurance.

Design/methodology/approach - A qualitative study was employed involving analyses of documents; interviews and focus group discussion with senior administrators, academic staff, students; and on-site observation in locations of teaching and learning.

Findings - This research is exploratory in nature. Findings of the study are expected to improve our understanding of student support in distance learning, in which analysis is based on good practices, challenges and rooms for improvement of both OUSL and UT.

Practical implications - Findings of this study reveal practices and lessons learnt that may be useful as reference to open universities, taking into considerations the fact that each open university has been established to address specific challenges in its own unique circumstances.

Originality/value - This research may be adopted as baseline framework for analysis of student support for open universities. Further in-depth study is needed to understand how various aspects of student support contribute to success in open and distance learning.
\end{abstract}

Keywords Open and distance education (ODE), Online learning, Flexible learning

Paper type Research paper

\section{Introduction and literature review}

Higher education systems are confronted with the tasks of addressing the differing needs of students using learning technology that allows them to learn in a more open and flexible manner, and share common goals relating to access, retention, flexibility and employability (European Commission/EACEA/Eurydice, 2014). In Asia, higher education systems are expanding to accommodate more students at undergraduate and post-graduate levels, and now increasingly focusing more on continuous quality improvements (UNESCO, 2014). Advances in technology challenge higher education further to transform themselves into addressing the changing needs of the world of work and to provide access and quality

(C) Aminudin Zuhairi, Navaratnasamy Karthikeyan and Saman Thushara Priyadarshana. Published in Asian Association of Open Universities Journal. Published by Emerald Publishing Limited. This article is published under the Creative Commons Attribution (CC BY 4.0) licence. Anyone may reproduce, distribute, translate and create derivative works of this article (for both commercial and non-commercial purposes), subject to full attribution to the original publication and authors. The full terms of this licence may be seen at http://creativecommons.org/licences/by/4.0/legalcode

Received 14 September 2019 Revised 30 October 2019 30 October 2019

Accepted 31 October 2019 
AAOUJ 15,1

14

education in more flexible fashions. New approaches and technologies have been using distance and blended learning and increasing roles of open universities in widening of participation in higher education (Latchem and Jung, 2010). Online learning is viewed as one of the effective instruments for widening access and providing flexibility for continuous professional development and lifelong learning. Student learning success poses a constant challenge to open and distance education institutions.

This paper addresses student support in open and distance education, including aspects related to instructional design and development, student engagement and motivation, university policy and strategy to reduce dropouts, use of OER/MOOCs, and quality assurance. The conceptual framework for student support services in open and distance learning (ODL) can be described in Figure 1.

Two institutions were investigated in this study, namely the Open University of Sri Lanka (OUSL) and Universitas Terbuka (UT) Indonesia, both of which are legacies of the 1980s during which open universities were established in many countries to respond to the needs for higher education worldwide. Founded in 1980 in Sri Lanka, and in 1984 in Indonesia, OUSL and UT have been assigned by their respective to accommodate in-service teachers, working adults, and high school graduates, and these roles remain relevant until today. As technology advances, both open universities have also been in the continuous process into transformation to become modern open universities using new technology in teaching and learning and management of their services. These developments of two open universities into their current state are worth being investigated. This study was made possible by the AAOU Inter-University Staff Exchange Fellowship 2019 offered by OUSL.

\section{Student support services}

Student support in ODL has been a fundamental question to address since ODL system has existed. Despite the transformation of ODL into a technology-based system, the principles of support services for distance learners remain the same, in which students are engaged in learning and motivated to learn independently and autonomously. Recent research highlights the importance of academic and non-academic support and the roles of

Figure 1.

Conceptual framework for student support services in open and distance education

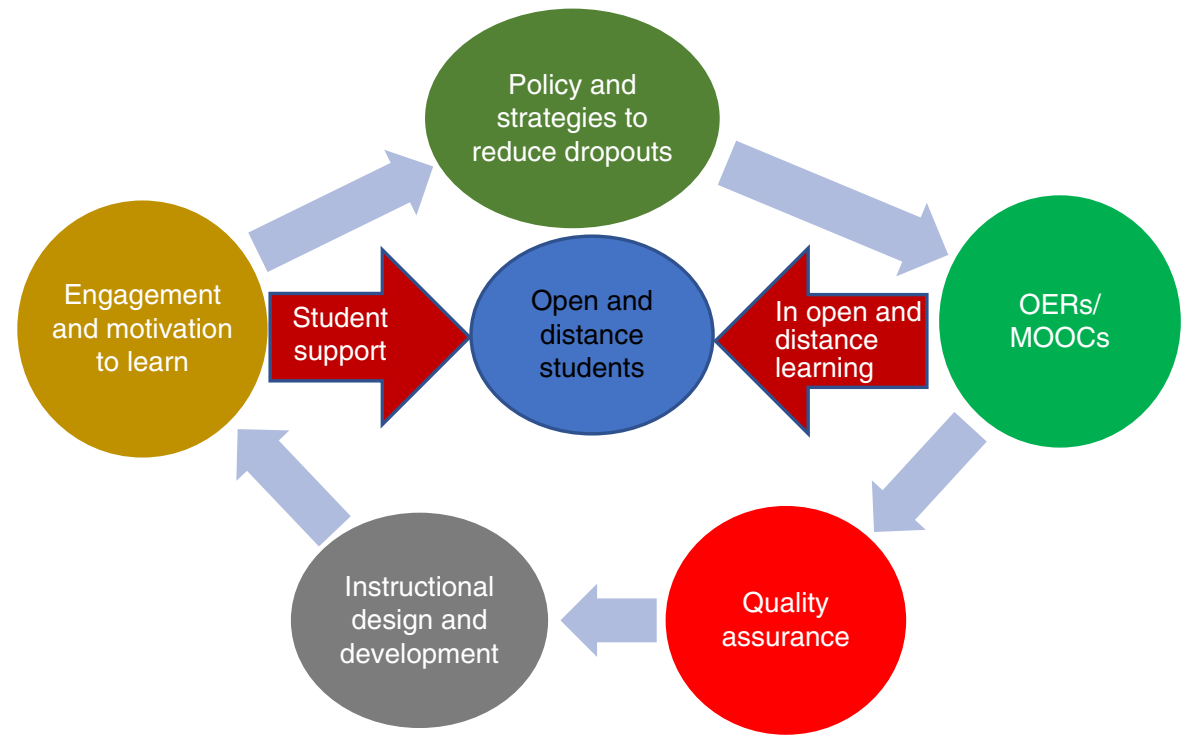


technologies to enable the development of more flexible, interactive and personalized learning environments that require new ways of providing learning support for open, distance and online students (Sánchez-Elvira Paniagua and Simpson, 2018). Earlier, Tait (2003) explained that distance students need support for three reasons, namely the needs for support, the reduction of dropout and the nature of learning. The primary functions of student support in ODL can be viewed as being related to the cognitive, affective, and systemic aspects, and the framework for the development of planning student support services is founded upon six core elements, namely student characteristics, course or program demands, geography, technology, scale and management systems (Tait, 2000). Tait (2014) evaluates the impact of digital technologies on student support in distance and e-learning, and further proposes that student support should now be understood as integrated with teaching and assessment. Tait (2014) further calls for reforming student support in the digital age taking into accounts both internal and external factors to the students and integrating student support with teaching. Further questions arise as regards to the kinds of effective support to students, how they are designed to meet the needs of ODL students, and how student support is integrated with teaching and learning.

\section{Student engagement and motivation in open distance education}

Educators have given increasing attention to engaging students in learning and motivating them to learn and how it is conducted in different learning and teaching contexts. Student engagement involves the interaction between the time, effort and resources invested by students and the institutions to optimize learning experience, enhance learning outcomes, and develop the students' performance and the institution's reputation (Trowler, 2010). Engaging students in learning is important to ensure persistence and improves academic achievement (Everett, 2015). Research has been conducted on various aspects of engagement of open and distance students in learning and findings confirm the importance of engagement of students in learning to ensure success in learning (Senior et al., 2018; Messias et al., 2015; Khe et al., 2018). There are questions to address as regards to what activities are designed and implemented to engage students in distance learning, how these activities are monitored and evaluated, and how distance students take advantage of learning engagement activities.

\section{Instructional design and development in open and distance learning}

The application of instructional design and development has evolved in line with the findings of research in education and psychology of learning and advances in technologies for teaching and learning. The role of instructional design is critical in open and distance education as distance learners are physically or geographically separate from their teachers. The instructional design process involves the identification the learners' needs, definition of instructional objectives, design of assessment, and design teaching and learning activities to ensure quality instruction (Educational Technology, 2019). Distance students are prepared to develop independent learning capability, motivate themselves to learn and engage themselves in learning activities that make them persistent and successful in learning. Open and distance education institutions are further challenged to transform themselves into the digitalization of learning and teaching, taking into accounts the learning needs and the technology supports required for learning. It is the task of distance educators to support learning and make distance learning experience enjoyable to students. Further questions are then which instructional design and development is suitable in distance learning, how media are incorporated into the learning experience of distance students, and how distance learning activities are designed and developed to motivate students to learn.
Supporting students to succeed in ODL 
AAOUJ

15,1

\section{Policy and strategy to reduce dropouts}

Dropout poses a critical challenge to prevent in higher education and it affects individuals, institutions, governments and stakeholders (Kim and Kim, 2018; European Commission, 2015; Stiburek et al., 2017). Research findings on factors affecting dropout in higher education have been conducted in different regions across different cultural contexts and addressed dropout as a serious issue that deserves specific attention and prevention (Bozkurt and Akbulut, 2019; Willging and Johnson, 2004; Kotsiantis et al., 2003). Findings of research conducted by Kim and Kim (2018) focusing on four categories on students, resources, faculty, and university characteristics indicate significant effects of those categories on university dropout. Earlier research conducted by Park and Choi (2009) has indicated that factors related to family support, organizational support, satisfaction and relevance in addition to individual characteristics is able to predict learners' decision to drop out or persist. The findings of the study imply that lower dropout rates can be achieved if online program developers or instructors find ways to enhance the relevance of the course, and that adult learners need to be supported by their organizations for them to finish online courses (Park and Choi, 2009). These findings provide insights into how dropout is to be understood and how interventions in distance learning is to be implemented to prevent dropout. Intervention supports distance students (Simpson, 2004), and proactive interventions and motivating learners in open and distance education is critical to successful learning accomplishments (Simpson, 2004, 2008). Further questions then how dropouts can be prevented, what learning activities are designed and developed to reduce dropouts, and what are the roles of the distance educators and media.

\section{OER/MOOCS}

OER is a new concept introduced thanks to advances in the use of internet and new technology that has enabled open knowledge resources accessible in easier modes. Illustrated by OECD (2007) as "giving knowledge for free," the important point of OER is that knowledge should be made available to facilitate learning. The emergence of OERs is transforming the landscape of teaching and learning at different levels and modes of education (Berti, 2018; Blomgren, 2018; Miao et al., 2016). Researchers have elaborated the potential benefits of OER from the different perspectives of government, institution, educator, and learner, and further put forwards some critical challenges of utilizing OERs related to the technical, economic, social and legal domains (Berti, 2018; Hatzipanagos and Gregson, 2015). Guidelines have been published to provide higher education institutions with reference in the use OER in the teaching and learning (UNESCO and COL, 2015). The sustainability of OER will remain to be challenged in terms of its effectiveness in ensuring student learning to take place (Wiley, 2007). Open universities have critical roles in the widening of participation in higher education through innovations and taking advantage of the integration of OER in teaching and learning, and thus new policies and practices are required at all levels in the higher education system to address issues of openness and the role that OERs can play in increasing and widening engagement and participation in learning (Lane and Van Dorp, 2011).

MOOCs are new trends in higher education, and open universities are the natural practitioners of massive open online learning courses, as the name open university suggests. From the beginning open universities enroll massive number of students studying ODL and later online courses. The open universities themselves have gone through stages of transitions from the printed correspondence, multimedia broadcast and more recently new technology and online supported distance learning. Some questions regards to how open universities take advantage of OER/MOOCs, integrate OER/MOOCs into supporting learning, and select OER/MOOCs to benefit student learning have been addressed by Karunanayaka and Naidu, 2014, 2016). 
Quality assurance in $O D L$

Quality assurance has been driven by the motive for continuous improvement and pressures for accountability, accreditation and external recognition. Distance education institutions have implemented quality assurance system to ensure certain level of quality can be achieved and continuously improved. Internal and external quality reviews are conducted in open and distance education institutions to meet quality requirements and stakeholders' expectations. Assuring quality of open and distance education is a complex effort, involving investment in time, resources, and multiple activities covering both academic processes and administrative services. Further questions emerge as regards what quality assurance system is implemented, how do the institutions establish quality assurance cultures across different levels and functions of the organization, and how quality assessment is conducted internally and externally.

\section{Research method}

This qualitative study involved interviews and focus group discussions with administrators, academic staff, and students, which lasted for about one hour each sessions, and was conducted in OUSL Head Office and three Regional Centers (RC) in Colombo, Kandy and Jaffna. Brief observation of teaching and learning and support service activities was conducted in the OUSL Head Office and in the three RC to have insights into how the various aspects of student support were implemented. Analysis of documents included institutional documents such as annual reports, research publications and internal policy documents and procedures. This study aimed at revealing insights into the provision of student support services, taking into accounts other supporting aspects related to student instructional design and development, engagement and motivation, policy and strategy in reducing dropout rates, use of OER/MOOCs, and quality assurance in ODL.

\section{Findings and discussion}

OUSL and UT were examined and analyzed in terms of good practices, challenges and rooms for improvement in student support as described in the conceptual framework, including instructional design and development, learner motivation and engagement, policy and strategies to reduce dropouts, OER and MOOCs, and quality assurance. Findings of this study were the results of the focus group discussions with people consulted during the study at OUSL (see Appendix) and analyses of documents.

\section{OUSL and UT as institutions}

OUSL and UT are single mode open universities established in the 1980s to address demands by the society for access, equity and participation in higher education, following up the success of the UK Open University. As open universities, both OUSL and UT have made significant contributions to human resource development of their respective countries. Large number of students coming from various backgrounds and locations have studied and graduated from both institutions. Employers and stakeholders acknowledge the quality and competence of graduates from the two open universities. It is useful to analyze higher education systems as academic institutions characterized as having six elements of cultures, namely collegial, managerial, developmental, advocacy, virtual and tangible (Bergquist and Pawlak, 2008), in which one character has evolved from negotiating to advocacy element, and two more elements of virtual and tangible have been added from earlier four elements (Bergquist, 1992). These expanding elements of cultures of academic institutions, namely virtual and tangible, have indicated how fast academic institutions have transformed themselves in recent times.
Supporting students to succeed in ODL 


\section{AAOUJ 15,1}

\section{8}

\section{Good practices of the institution}

Despite the similarities of both open universities, the findings of this study reveal the unique characters of each of the institutions in response to the specific needs and contexts each of which has been established. Both OUSL and UT are academic institutions sharing common characteristics, core values and missions although each institution differs in the ways it provides academic services to addresses the specific needs of their respective clients. They are different in terms of institutional cultures and the way each institution provides services to students, due to geographic, demographic and other conditions. The way they address the needs of the society is further reflected in the kinds and variety of study programs each institution offers to the clientele. It is interesting to observe that OUSL charges student fees while its respective conventional counterparts are fully funded by the government through the Sri Lanka's University Grants Commission. Fees charged to UT students, on the other hand, are considered as the lowest among state higher education institutions that also rely on government funding. Table 1 presents a summary of findings in good practices of OUSL and UT, revealing aspects related to academic service provision, institution culture, core value, programs offered, mission and tuition fees.

\section{Challenges of institution}

Both OUSL and UT are confronted with challenges to address, and each would have to respond in ways that are unique depending on their respective contexts, needs, and certain conditions that allow them for effective implementation. New technology offers both challenges and opportunities for open universities and higher education through potential uses of online learning to improve access and quality. Higher education institutions including open universities are challenged to open its doors to a variety of backgrounds of student population and provide quality higher education using the best available technology within easy and flexible access by students. New technology has reoriented higher education institutions and open universities to shifting their paradigm to become

\begin{tabular}{|c|c|c|}
\hline Aspects & OUSL & UT \\
\hline $\begin{array}{l}\text { Academic } \\
\text { service } \\
\text { provision }\end{array}$ & $\begin{array}{l}\text { Academic services relying on its own } \\
\text { resources: academic, human, } \\
\text { infrastructure, facilities }\end{array}$ & $\begin{array}{l}\text { Academic services based on resource- } \\
\text { sharing through partnerships with other } \\
\text { institutions: academic, human, } \\
\text { infrastructure, facilities }\end{array}$ \\
\hline $\begin{array}{l}\text { Institution } \\
\text { culture }\end{array}$ & $\begin{array}{l}\text { Strong academic cultures with academic } \\
\text { staff responsible to academic departments; } \\
\text { responsibilities for face-to-face, practical and } \\
\text { online teaching; research activities }\end{array}$ & $\begin{array}{l}\text { Strong management of partnership cultures; } \\
\text { centralized management and control; } \\
\text { academic services such as face-to-face and } \\
\text { online tutorials relying on external } \\
\text { academics; academic responsibilities in } \\
\text { monitoring and supervisory roles using } \\
\text { certain quality criteria }\end{array}$ \\
\hline Core value & $\begin{array}{l}\text { Providing quality open and distance higher } \\
\text { education to all citizens }\end{array}$ & Making quality higher education open to all \\
\hline $\begin{array}{l}\text { Programs } \\
\text { offered }\end{array}$ & $\begin{array}{l}\text { A very broad range of academic programs } \\
\text { from social sciences to engineering and } \\
\text { science lab-based courses at all levels }\end{array}$ & $\begin{array}{l}\text { A broad range of academic programs with } \\
\text { very large number of students at all levels, } \\
\text { including in science and technology courses }\end{array}$ \\
\hline Mission & $\begin{array}{l}\text { Reach out students denied by conventional } \\
\text { university system and working adults }\end{array}$ & $\begin{array}{l}\text { Reach out all high school graduates, those } \\
\text { living in emote and rural areas, working } \\
\text { adults, and everybody else }\end{array}$ \\
\hline Fees & $\begin{array}{l}\text { Funded by the government, rely on tuition } \\
\text { fees from students who pay a lot more } \\
\text { compared to conventional universities } \\
\text { that charge no fees }\end{array}$ & $\begin{array}{l}\text { Funded by the government, rely on student } \\
\text { fees, manage services effectively, known as } \\
\text { the lowest fees among state universities }\end{array}$ \\
\hline
\end{tabular}

Table 1.

Good practices of the institution compared to conventional universities that charge no fees 
more technology enhanced in teaching and learning as well in management. These paradigm shifts into integration of new technology have put pressures on the needs for continuous training and careful reviews of teaching workloads of staff. There are also demands by governments and stakeholders for open and higher education institutions to accommodate larger numbers of students so that institutions must explore and invent new methods and ways to meet these growing demands for access and quality. Table 2 presents detail challenges of both OUSL and UT as open universities in aspects relating to number of students, integration of online learning, access to a variety of services, new technology, staff training needs, academic staff workload and resources needed, admission policy and period of study.

\section{Rooms for improvement for institution}

OUSL and UT have rooms for improvement to respond to stakeholders' needs and expectations. Both institutions share common areas for improvements in aspects related to strengthening of student support system, improving participation rate in higher education, promoting lifelong learning, and establishing partnership and diversity of programs. Both OUSL and UT are under pressures by the Government to widen access, improve participation rates in higher education, and expand lifelong learning programs. Partnership can be one instrument to accommodate more students and diversify programs in response to the needs of stakeholders and in anticipation to the 4.0 industry for new skilled workforce. Alongside common opportunities for improvement of both institutions, there can be differences in emphases depending upon the priorities and intensities in which those challenges are confronted by each of the institutions. Table 3 elaborates rooms for improvement to be considered by OUSL and UT.

\section{Student support}

Open and distance education students need student support to facilitate, engage and motivate students to learn. These student support needs include areas academic, administrative and other matters needed by distance students to succeed in learning. As earlier noted by Tait (2014), student support for distance learners are further challenged as the result of the digitalization and the need for integration of learning, assessment, and student support in online learning environment.

\begin{tabular}{|c|c|c|}
\hline Aspects & OUSL & UT \\
\hline Number of students & $\begin{array}{l}\text { Accommodate larger number of } \\
\text { students }\end{array}$ & $\begin{array}{l}\text { Serve more distributed and very large number } \\
\text { of students with different needs }\end{array}$ \\
\hline $\begin{array}{l}\text { Integrating online } \\
\text { learning }\end{array}$ & $\begin{array}{l}\text { Transformation into integrating } \\
\text { online learning }\end{array}$ & $\begin{array}{l}\text { Transforming into online and cyber university } \\
\text { education and competition among online } \\
\text { learning providers }\end{array}$ \\
\hline $\begin{array}{l}\text { Access to a variety } \\
\text { of services }\end{array}$ & $\begin{array}{l}\text { More widely accessible to diverse } \\
\text { groups of students from different } \\
\text { economic capacities }\end{array}$ & $\begin{array}{l}\text { Improved services to diverse groups of } \\
\text { students with different needs and access to } \\
\text { various modes of services }\end{array}$ \\
\hline New technology & $\begin{array}{l}\text { Incorporating more uses of new } \\
\text { technologies to enrich learning } \\
\text { experience of students }\end{array}$ & $\begin{array}{l}\text { Incorporating more uses of new technologies } \\
\text { to enrich learning experience of students }\end{array}$ \\
\hline Staff training needs & $\begin{array}{l}\text { Staff training in new technology, OER } \\
\text { and MOOCs }\end{array}$ & $\begin{array}{l}\text { Staff training in new technology, OER and } \\
\text { MOOCs }\end{array}$ \\
\hline $\begin{array}{l}\text { Academic staff } \\
\text { workload }\end{array}$ & $\begin{array}{l}\text { Academic staff workload and } \\
\text { substitute resources needed }\end{array}$ & $\begin{array}{l}\text { Resources for programs in engineering, health } \\
\text { sciences and hard sciences }\end{array}$ \\
\hline Admission policy & Selection criteria apply & Open admission to all \\
\hline Period of study & 3 times normal years of completion & Lifelong learning, no dropout \\
\hline
\end{tabular}

Table 2.

Challenges of institution
Supporting students to succeed in ODL 


\begin{tabular}{|c|c|c|c|}
\hline \multirow{3}{*}{$\begin{array}{l}\text { AAUUJ } \\
15,1\end{array}$} & Aspects & OUSL & UT \\
\hline & Student support & Strengthen online learning support & \multirow{4}{*}{$\begin{array}{l}\text { Continuously improve the quality of online } \\
\text { learning support } \\
\text { Offer programs in engineering and hard } \\
\text { sciences in selected ROs to meet diverse } \\
\text { groups of student's needs } \\
\text { Strengthen short training courses and } \\
\text { lifelong learning programs } \\
\text { Establish laboratories in HO and selected } \\
\text { ROs for academic staff and graduate } \\
\text { students to diversify programs, and } \\
\text { improve the quality of dry labs }\end{array}$} \\
\hline & $\begin{array}{l}\text { Participation rate } \\
\text { in higher } \\
\text { education }\end{array}$ & $\begin{array}{l}\text { Accommodate more students to improve } \\
\text { participation rates in higher education }\end{array}$ & \\
\hline 20 & Lifelong learning & Continuously improve and expand short & \\
\hline $\begin{array}{l}\text { Table } 3 . \\
\text { Room for } \\
\text { improvement of } \\
\text { the institution }\end{array}$ & $\begin{array}{l}\text { Partnership to } \\
\text { accommodate } \\
\text { more students }\end{array}$ & $\begin{array}{l}\text { training courses } \\
\text { Consider establishing partnerships to } \\
\text { enable accommodating more students into } \\
\text { the ODL system effectively }\end{array}$ & \\
\hline
\end{tabular}

\title{
Good practices in student support
}

Student support plays key roles in ODL, and open universities have designed various methods and ways of learning supporting to respond to the specific needs of students. Student support covers a broad range of services, including academic, administrative, and other services to ensure successful learning process of distance students. Both OUSL and UT focus on the students at the center of attention to support services. A variety of modes for student support are employed involving the use of media, face-to-face interaction, and recently online support. One key point is continuous support provided by both institutions to ensure that students get the right support by the right persons during their studies. These student support services are provided centrally by the Head Office as well as distributed

\begin{tabular}{|c|c|c|}
\hline Aspects & OUSL & UT \\
\hline Student focus & $\begin{array}{l}\text { Focus on student learning support including } \\
\text { use of resources, learning conditions, design } \\
\text { of activities, and assessment by academics } \\
\text { on campus in HO, RC and SC }\end{array}$ & $\begin{array}{l}\text { Focus on student learning support involving } \\
\text { external academics and resources in diverse } \\
\text { and distributed locations supported by } \\
\text { partner institutions }\end{array}$ \\
\hline $\begin{array}{l}\text { Modes of } \\
\text { support }\end{array}$ & $\begin{array}{l}\text { Provision of learner support through various } \\
\text { modes: face-to-face, mediated, learning } \\
\text { engagement activities, and practical } \\
\text { experiences }\end{array}$ & $\begin{array}{l}\text { Provision of learner support through various } \\
\text { media and different modes of learning } \\
\text { support, and differentiated fees for different } \\
\text { kinds of support }\end{array}$ \\
\hline $\begin{array}{l}\text { Interactive } \\
\text { support }\end{array}$ & $\begin{array}{l}\text { Online forum, face-to-face interaction, } \\
\text { peer supported learning, support by senior } \\
\text { students }\end{array}$ & $\begin{array}{l}\text { Contact Center, online forum, } \\
\text { face-to-face interaction }\end{array}$ \\
\hline $\begin{array}{l}\text { Delivery } \\
\text { of support }\end{array}$ & $\begin{array}{l}\text { Learner support distributed through } \\
\text { Regional Centers by academic staff } \\
\text { and administrative staff }\end{array}$ & $\begin{array}{l}\text { Learner support by face-to-face tutors in } \\
\text { locations close to students, support by online } \\
\text { tutors, and access to centralized Contact } \\
\text { Centre and to Regional Office }\end{array}$ \\
\hline $\begin{array}{l}\text { Continuous } \\
\text { support }\end{array}$ & $\begin{array}{l}\text { Continuous need for learner support t } \\
\text { o motivate all students in a } \\
\text { learning community }\end{array}$ & $\begin{array}{l}\text { Provide development of students' distance } \\
\text { and independent learning skills and } \\
\text { increasing use of online support }\end{array}$ \\
\hline Online support & $\begin{array}{l}\text { Online academic support provided by } \\
\text { academics and other support by } \\
\text { relevant units }\end{array}$ & $\begin{array}{l}\text { IT-based students support, Moodle, cloud } \\
\text { computing, licensed Microsoft Office } 365\end{array}$ \\
\hline $\begin{array}{l}\text { Responsibilities } \\
\text { for support }\end{array}$ & $\begin{array}{l}\text { Autonomous responsibility of academic } \\
\text { departments and individual academic } \\
\text { members with Faculty and } \\
\text { department timelines }\end{array}$ & $\begin{array}{l}\text { Institutional responsibility shared by all } \\
\text { academic departments and staff for } \\
\text { implementation with common } \\
\text { institution-wide timeline }\end{array}$ \\
\hline
\end{tabular}

Table 4.

Good practices in student support

\begin{abstract}
through OUSL RC and Study Centers (SC) as well UT Regional Offices (RO). Table 4
\end{abstract}


illustrates findings of the study in terms of good practices of OUSL and UT in student support in aspects related to focus on students, modes of support, interactive support, delivery of support, online support, continuous support and responsibilities of relevant units and staff to provide student support.

\section{Challenges in student support}

Both OUSL and UT are confronted with challenges in the provision of effective support. Advances in technology have shifted the paradigm of open universities from its traditional format of open and distance education into integrating online support in both academic and administrative services. Table 5 indicates findings in challenges of student support confronted by OUSL and UT, with emphases on aspects related to online support for all students, management of support, sharing methods of support and development of online cultures in student support.

\section{Rooms for improvement in student support}

Despite the challenges ahead, there are rooms to improve student support system for consideration into implementation by OUSL and UT, in which ways and means of improvement may vary because of the cultures of each institution, scale of operation, and kinds of program each offers to students. Both institutions have attempted specific attention to address individual learning needs of students. Table 6 indicates details of rooms for improvement in student support for OUSL and UT in aspects related to access to learning resources and addressing needs of students, partnerships and emphasis on zero defects, addressing diverse groups of students, and admission and monitoring of student learning progress.

\section{Instructional design and development}

Instructional design and development are the foundation of any education system, and it is particularly challenging for ODL that have physical, temporal, and transactional distance between students and their teachers. In any educational process, instructional design and development need to be carefully prepared for effective implementation, and for open and distance education it must be accurately delivered with systematic supply chain management and logistic support.

\section{Good practice in instructional design and development}

Both OUSL and UT have existed and will continue to exist to provide well-designed and well-developed open and distance education programs. Both institutions share commonalities

\begin{tabular}{|c|c|c|}
\hline Aspects & OUSL & UT \\
\hline Online support & $\begin{array}{l}\text { Large-scale online support in all } \\
\text { courses for large number of } \\
\text { online students }\end{array}$ & $\begin{array}{l}\text { Quality improvement of online support in terms of } \\
\text { technology, capacity, interactivity, feedbacks and } \\
\text { content }\end{array}$ \\
\hline $\begin{array}{l}\text { Management } \\
\text { of support }\end{array}$ & $\begin{array}{l}\text { Faculties have learner support } \\
\text { system to be shared with each other }\end{array}$ & $\begin{array}{l}\text { Centralized universal support system for all } \\
\text { courses across Study Programs and Faculties, } \\
\text { whilst programs may have unique characteristics } \\
\text { and needs }\end{array}$ \\
\hline $\begin{array}{l}\text { Sharing methods } \\
\text { of support }\end{array}$ & $\begin{array}{l}\text { Establish the culture of sharing } \\
\text { among Faculties and academic } \\
\text { departments }\end{array}$ & $\begin{array}{l}\text { Customize support services for Study Programs } \\
\text { with certain characteristics and needs }\end{array}$ \\
\hline $\begin{array}{l}\text { Development of } \\
\text { online cultures }\end{array}$ & $\begin{array}{l}\text { Develop stronger online learning } \\
\text { and teaching environment } \\
\text { and cultures }\end{array}$ & $\begin{array}{l}\text { Continue to improve stronger online learning } \\
\text { and teaching environment and cultures using } \\
\text { latest technologies }\end{array}$ \\
\hline
\end{tabular}

Table 5.

Challenges in student support
Supporting students to succeed in ODL 


\section{AAOUJ 15,1}

Table 6.

Room for improvement in student support

\begin{tabular}{lll} 
Aspects OUSL & UT \\
\hline
\end{tabular}

Address specific Improve access to various learning needs of students support, particularly online support

Improve access to various learning resources and provide specific attention to individual learning needs of students Enhance partnerships and ensure zero

Partnership and zero defects

Establish partnerships with other institutions to participate in distance and defects to ensure common timelines, large online learning scale logistic and supply chain management, and operational services can be effectively provided

Diverse groups of Explore new ways of supporting diverse Invent new ways of supporting specific students groups of students with different needs for online learning groups of students with specific needs but limited access for online learning

Admission and monitoring of learning progress
Be more open in terms of admission, and Monitor learning progress and start addressing individual needs of students using learning analytics to support student learning

in instructional design and development principles, although they may have differences in terms of their ways and procedures for instructional design and development. Table 7 presents detail findings of OUSL and UT good practices in instructional design and development in aspects related to new student orientation and study skills development, independent learning skills, peer learning, online interaction, course team approach, design for

online learning, and roles of course coordinator or manager.

\begin{tabular}{|c|c|c|}
\hline Aspects & OUSL & UT \\
\hline New student & $\begin{array}{l}\text { START@OUSL = Student Academic } \\
\text { Readiness Training Program to prepare } \\
\text { students in ODL }\end{array}$ & $\begin{array}{l}\text { New student orientation and development of } \\
\text { distance learning skills }\end{array}$ \\
\hline $\begin{array}{l}\text { Independent } \\
\text { learning }\end{array}$ & $\begin{array}{l}\mathrm{EFIL}=\text { Empowerment for independent } \\
\text { learning }\end{array}$ & Development of independent study skills \\
\hline Peer learning & $\begin{array}{l}\text { PASS = Peer Assisted Support Services } \\
\text { to help junior students }\end{array}$ & $\begin{array}{l}\text { Tutor assisted student support face-to-face } \\
\text { or online, and peer learning in tutorials }\end{array}$ \\
\hline Online interaction & $\begin{array}{l}\text { Online discussion forum and access to } \\
\text { academic staff and resources in HO, RCs } \\
\text { and SCs }\end{array}$ & $\begin{array}{l}\text { Online discussion forum, access to } \\
\text { Contact Center }\end{array}$ \\
\hline $\begin{array}{l}\text { Course team } \\
\text { approach }\end{array}$ & $\begin{array}{l}\text { Course team approach to develop } \\
\text { self-instructional learning materials } \\
\text { involving external reviewers }\end{array}$ & $\begin{array}{l}\text { Course team approach to develop } \\
\text { self-instructional learning materials by } \\
\text { senior academics from partner universities } \\
\text { coordinated by Course Manager }\end{array}$ \\
\hline Design for online & Introduction & Introduction \\
\hline learning & Information & Initiation \\
\hline \multirow[t]{5}{*}{ components } & Assessment & Explanation \\
\hline & Learning resources & Questions to discuss \\
\hline & Online class discussion & Discussion \\
\hline & Questions & Assignments \\
\hline & Exam papers model & Feedbacks \\
\hline \multirow{6}{*}{$\begin{array}{l}\text { Responsibilities of } \\
\text { course coordinator } \\
\text { or manager }\end{array}$} & Design the course & Manage the process and activities for \\
\hline & Prepare course materials & Curriculum and course development \\
\hline & Deliver course materials & Writing of courses printed and non-printed \\
\hline & Organize the course within the & Writing of test items and exam papers and \\
\hline & $\begin{array}{l}\text { Department } \\
\text { Prepare exam papers }\end{array}$ & $\begin{array}{l}\text { test items } \\
\text { Design face-to-face and online tutorials }\end{array}$ \\
\hline & & Maintenance of courses \\
\hline
\end{tabular}

Table 7.

Good practices instructional design and development 


\section{Challenges instructional design and development}

OUSL and UT share common challenges to have instructional design and development able to meet the changing needs of ODL and the paradigm shift to online learning. The instructional design and development aim to engage and motivate students to learn independently and autonomously and meet certain criteria for ODL. Table 8 presents challenges in instructional design and development in aspects relating to design for engagement and motivation to learn; quality assurance in the design, development, and delivery process; and instructional design for online and fully online courses.

\section{Rooms for improvement instructional design and development}

Both OUSL and UT share common areas for improvement in terms of expanding and improving the quality of their online courses, except for the scale that is larger for UT than that of OUSL. Use of OER to enrich student learning experience and MOOCs to promote lifelong learning is one area that both institutions have attempted to do more and encourage staff to provide better delivery for the online courses and tutorials. Research in the area of online instructional design and development is one area in which both need to focus for continuous improvement. Research in instructional design and development is the basis for improving the quality of distance and online learning process that eventually results in success in achieving learning objectives. As illustrated in Table 9 below, both OUSL and UT share common areas in instructional design and development for improvement in aspects related to online courses, OER, MOOCs and research in instructional design and development.

\section{Engagement and motivation to learn}

Engagement and motivation in learning for distance students play crucial roles in ensuring student learning and they may involve a variety of teaching and learning as well as assessment activities. Learning engagement and motivation is the essence of teaching and learning process that need to be closely monitored in terms of its implementation and progress. and progress.
Supporting students to succeed in ODL

\begin{tabular}{ll}
\hline Aspects & OUSL and UT common challenges \\
\hline $\begin{array}{l}\text { Design for online learning } \\
\text { Design for engagement } \\
\text { and motivation }\end{array}$ & $\begin{array}{l}\text { Instructional design and development for online learning } \\
\text { Duality assurance in the }\end{array}$ \\
$\begin{array}{l}\text { Design for effective learning engagement and motivation in online learning } \\
\text { Fully online courses }\end{array}$ & $\begin{array}{l}\text { Quality assurance in the design, development, and delivery process in } \\
\text { online learning } \\
\text { Add more and continuously improve the quality of online courses and } \\
\text { programs; integrating teaching learning and assessment }\end{array}$
\end{tabular}

Table 8.

Challenges in instructional design and development

\begin{tabular}{ll}
\hline Aspects & OUSL and UT common rooms for improvement \\
\hline Online courses & Continuously improve and expand online courses \\
OER & Increasing use of OERs \\
MOOCs & Use of MOOCs to promote fully online learning courses \\
Research & Research in instructional design and development of online learning
\end{tabular}

Table 9.

Rooms for improvement in instructional design and development 


\section{AAOUJ 15,1}

\section{Good practices in engagement and motivation to learn}

Both OUSL and UT share common good practices to engage and motivate learners, taking seriously the business of new student orientation and the development of student distance learning skills and independent study skills, tutorial support, practical components and online learning activities. Intervention in learning and notifications for continuous studies are delivered to students as parts of the effort to motivate students to learn. Eligibility criteria are set for OUSL to ensure students take distance studies seriously in order to pass eligibility criteria prior to taking the final exam for the course. For UT, students are motivated to study and pass certain criteria for the minimum score of the semester examination. These good practices may be relevant to share and consider for other open, distance, and online education system. Table 10 presents good practices of both OUSL and UT in engagement and motivation to learn, particularly in aspects related to new student orientation, tutorial support, practical components, eligibility criteria, intervention in learning, notifications and reminders sent out to students, and online components of teaching and learning.

\section{Challenges in engagement and motivation to learn}

There are common challenges in engagement and motivation to learn confronted by OUSL and UT, in which both start to emphasize the importance of learning and teaching in online environment and its continuous improvement. In the case of the quality improvement of online teaching-learning and other services, the stakeholders' involvement becomes critical as the quality of online access will highly depend upon the telecommunication infrastructure and facilities on the parts of the institution and access by students. Government policies on information communication and technology will play important roles in ensuring a conducive online learning environment. As indicated in Table 11, these challenges include aspects related to online teaching responsibilities of academic staff, increased use of e-learning platform by students and academic staff, online teaching competence, student learning engagement and stakeholders' involvement to facilitate ODL.

\begin{tabular}{|c|c|c|}
\hline Aspects & OUSL & UT \\
\hline $\begin{array}{l}\text { New student } \\
\text { orientation }\end{array}$ & $\begin{array}{l}\text { Peer learning (PASS) to engage in learning, } \\
\text { develop study habits, and give } \\
\text { motivational effects to pass exam }\end{array}$ & $\begin{array}{l}\text { New student orientation and development } \\
\text { of distance learning and independent } \\
\text { study skills }\end{array}$ \\
\hline Tutorial support & Day school to facilitate learning on campus & $\begin{array}{l}\text { Face-to-face tutorial support in locations } \\
\text { close to students and online tutorial } \\
\text { support, participation and interaction in } \\
\text { tutorial sessions, three assignments }\end{array}$ \\
\hline $\begin{array}{l}\text { Practical } \\
\text { components }\end{array}$ & $\begin{array}{l}\text { Practical components conducted in } \mathrm{RCs} \\
\text { supervised by academics and relevant staff }\end{array}$ & $\begin{array}{l}\text { Practical components in partner university } \\
\text { locations close to students' residences }\end{array}$ \\
\hline Eligibility criteria & Students to pass eligibility criteria/mark & $\begin{array}{l}\text { Minimum semester exam score to include } \\
\text { scores for tutorial assignments }\end{array}$ \\
\hline Intervention & $\begin{array}{l}\text { Intervention in learning: alert, testing } \\
\text { packages, counseling support, } \\
\text { student access }\end{array}$ & $\begin{array}{l}\text { Interaction in face to face and online } \\
\text { tutorials, contact support, academic } \\
\text { counseling, remediation }\end{array}$ \\
\hline Online components & $\begin{array}{l}\text { Online components include questions, } \\
\text { quizzes, extra notes, e-learning facilities, } \\
\text { papers, power points, online } \\
\text { discussion forum }\end{array}$ & $\begin{array}{l}\text { Online components include greetings, } \\
\text { questions, responses, feedbacks, peer } \\
\text { interaction, online discussions, OER }\end{array}$ \\
\hline Online notifications & $\begin{array}{l}\text { Online notifications and messages } \\
\text { to students }\end{array}$ & $\begin{array}{l}\text { Online notifications and messages } \\
\text { to students }\end{array}$ \\
\hline
\end{tabular}

Table 10.

Good practices in engagement and motivation to learn 
Rooms for improvement in engagement and motivation to learn

There are rooms for improvement in engagement and motivation to learn in online learning environment, in terms of the quality of initiations, interactions, feedbacks and instructor to student ratio. Staff and students need to be encouraged to use online learning platform to enhance and improve the quality learning and teaching experience. Table 12 indicates needed improvements in aspects related to active engagement in learning, engagement of staff in online learning, and encouragement to use of online learning.

\section{Policy and strategies to reduce dropouts}

Open universities suffer from dropouts, and there needs to be systematic effort to prevent students from dropout. New strategies need to be tried out and carefully evaluated. Further studies need to be conducted so that findings can be used to better understand why students drop out. Open universities need to further explore new ways and methods to prevent students from dropout.

\section{Good practices in policy and strategies to reduce dropouts}

Retaining students is a challenge faced by open and distance education system, including online learning system. There are ways and means of reducing dropouts as implemented by OUSL and UT. Prevention is one key effort to reduce dropouts, although it may not always be easy from the beginning for educators and the institutions to identify and predict which students may not continue and may eventually drop out from their distance studies. New student orientation and development of distance learning skills is perceived by both institutions as one key step for prevention, followed by continuous assessment, assignments, and provision of continuous support for the students during their studies. Table 13 indicates

\begin{tabular}{|c|c|}
\hline Aspects & Common challenges in engagement and motivation to learn for OUSL and UT \\
\hline $\begin{array}{l}\text { Online teaching } \\
\text { responsibilities }\end{array}$ & Engage academic staff in online teaching responsibilities \\
\hline $\begin{array}{l}\text { Use of e-learning } \\
\text { platform }\end{array}$ & Engage staff and students to use e-learning platform to get online learning experiences \\
\hline Online teaching & $\begin{array}{l}\text { Improve the quality of academic staff in online teaching engagement, interactivity } \\
\text { and feedbacks }\end{array}$ \\
\hline Learning engagement & Improve the quality of online learning engagement of students \\
\hline $\begin{array}{l}\text { Stakeholders } \\
\text { involvement }\end{array}$ & $\begin{array}{l}\text { Involve stakeholders to improve the quality of online infrastructure for the institution } \\
\text { and better access by students }\end{array}$ \\
\hline
\end{tabular}
and better access by students
Supporting students to succeed in ODL
Table 11.

Challenges in engagement and motivation to learn

\begin{tabular}{|c|c|c|}
\hline Aspects & OUSL & UT \\
\hline Active engagement & $\begin{array}{l}\text { Engaging students more actively in } \\
\text { online learning }\end{array}$ & $\begin{array}{l}\text { Improve the quality of online learning } \\
\text { management system: academic, } \\
\text { administrative, ratio, initiations, } \\
\text { interactions, feedbacks }\end{array}$ \\
\hline $\begin{array}{l}\text { Engagement of staff } \\
\text { in online learning and } \\
\text { teaching }\end{array}$ & $\begin{array}{l}\text { Engage more academic staff and } \\
\text { students to engage in online learning } \\
\text { and teaching }\end{array}$ & $\begin{array}{l}\text { Develop a system to encourage academic staff } \\
\text { and tutors in online teaching and engage } \\
\text { students in online learning }\end{array}$ \\
\hline $\begin{array}{l}\text { Encourage use of } \\
\text { online learning }\end{array}$ & $\begin{array}{l}\text { Encourage staff and students to use } \\
\text { e-learning platform to get online } \\
\text { learning experiences }\end{array}$ & $\begin{array}{l}\text { Continuously improve the quality of academic } \\
\text { staff and tutors in online teaching and } \\
\text { students to have online learning experiences }\end{array}$ \\
\hline
\end{tabular}

Table 12.

Rooms for improvement in engagement and motivation to learn 


\section{AAOUJ 15,1}

\section{6}

26

Table 13.

Good practices in strategies to reduce dropouts

\begin{tabular}{lll}
\hline Aspects & OUSL & UT \\
\hline Prevention & $\begin{array}{l}\text { Prevention of dropouts through } \\
\text { continuous support: induction, day } \\
\text { school, exam }\end{array}$ & $\begin{array}{l}\text { Prevention of dropouts through provision } \\
\text { of various learning support }\end{array}$ \\
$\begin{array}{l}\text { New student } \\
\text { orientation and study } \\
\text { skills development }\end{array}$ & $\begin{array}{l}\text { Readiness Training Program for new } \\
\text { students, EFIL Workshop, English, ICT, } \\
\text { student counseling before course } \\
\text { registration }\end{array}$ & $\begin{array}{l}\text { New student orientation, development of } \\
\text { distance learning and independent } \\
\text { studils }\end{array}$ \\
$\begin{array}{l}\text { Encourage students to take courses } \\
\text { Takpropriately, even less courses to ensure } \\
\text { appropriately }\end{array}$ & $\begin{array}{l}\text { Flexibility for students to choose the } \\
\text { appropriate mode of learning support to } \\
\text { suit individuals' learning needs and } \\
\text { personal conditions }\end{array}$ \\
$\begin{array}{l}\text { sussessment and } \\
\text { assignments }\end{array}$ & $\begin{array}{l}\text { Continuous assessment before final exam } \\
\text { for the course } \\
\text { Continuous support }\end{array}$ & $\begin{array}{l}\text { Provide support and assistance to } \\
\text { assignments, feedbacks }\end{array}$ \\
students with difficulties & $\begin{array}{l}\text { Remediation, learning clinics, assignment } \\
\text { clinics, examination clinics }\end{array}$
\end{tabular}

good practices in strategies to reduce dropouts in aspects related to prevention of dropouts, strengthening of new student orientation and study skills development, advice to students on taking courses appropriately, assessment and assignments, and continuous support to student learning.

\section{Challenges in policies and strategies to reduce dropouts}

Open universities also share common challenges in strategies to reduce dropouts, particularly for first year students. Special effort needs to be designed to identify students' strengths and weakness so that certain groups of students can be supported to continue their studies. Further challenges are effective implementation of such a prevention design mechanism for large number of students. Table 14 indicates strategies to reduce dropouts implemented by OUSL and UT in aspects related to supporting learning process for first year students and identification of "weak" students.

\section{Rooms for improvement in policy and strategies to reduce dropouts}

Improvement in strategies to reduce dropouts will be effective when the problems of dropouts and reasons for students' dropouts can be well understood earlier identified. This may not easily be mapped as open and distance students may have flexibility in terms of choices of courses, time spent for studying, and duration of study. Some key points may be considered for implementation, namely strengthening of student support; improved communication, interaction and feedbacks to students; and start using learning analytics in online learning. Table 15 indicates rooms for improvement in strategies to reduce dropouts in aspects related to strengthening student support, improved communication and interaction, and use of learning analytics.

\begin{tabular}{ll}
\hline Aspects & Common challenges to in strategies to reduce dropouts for OUSL and UT \\
\hline First year students & $\begin{array}{l}\text { More first year students drop out of the system, and the continuing trend in } \\
\text { the following years }\end{array}$ \\
$\begin{array}{l}\text { Identification of weak students } \\
\text { and follow up }\end{array}$ & $\begin{array}{l}\text { Strategies to identify weak students right from the beginning, then take } \\
\text { appropriate actions for prevention of dropouts }\end{array}$
\end{tabular}

Table 14.

Challenges in strategies to reduce dropouts 


\section{OER/MOOCs}

OER and MOOCs are new trends in higher education thanks to advances in digital interactive technology and invention of the internet. Higher education institutions vary in terms of adoption and integration of both advances into teaching and learning process. Awareness about OER and MOOCs and their potential effectiveness to support teaching and learning need to be continuously introduced constructed to academic staff, tutors, students and the society as parts of the effort to promote lifelong learning. Clear policies by the government and higher education institutions including open universities must be well stated for effective implementation supported with continuous evaluation and improvement so that OER and MOOCs benefit student learning.

\section{Good practices in OER and MOOCs}

It is observed that both OUSL and UT have experimented with the use of OER/MOOCs to enrich the students' learning experiences. Table 16 illustrates good practices of OUSL and UT in OER and MOOCs in aspects related to needs for staff training in OER and MOOCs, training of teachers in OER and MOOCs, OER integration into courses, establishing policies on OER, implementation and evaluation MOOCs, and trends in duration of MOOCs.

\section{Challenges in OER and MOOCs}

There are common challenges in the use of OER and MOOCs to enrich student learning experience in OUSL and UT. Effective use new technology and ideas normally begin with

\begin{tabular}{ll}
\hline Aspects & Common rooms for improvement to reduce dropouts for OUSL and UT \\
\hline Strengthening support & $\begin{array}{l}\text { Strengthen prevention through new student orientation, development of } \\
\text { distance learning and independent study skills with continuous monitoring }\end{array}$ \\
Improved communication & $\begin{array}{l}\text { Improve interaction, communication, counseling and feedbacks so that "ill } \\
\text { motivated" students can be supported to succeed in the course and } \\
\text { eventually program }\end{array}$ \\
Learning analytics & Start using learning analytics to help and support students in online learning
\end{tabular}

Supporting students to succeed in ODL

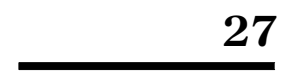


AAOUJ

15,1

\section{8}

awareness training then integration into the learning and teaching practices. There are external factors worth considering as regards IT infrastructure and facilities that are usually beyond the control of the institutions and students. Many OER and MOOCs are offered in English language. English language poses specific challenge for OUSL in which courses may be offered in Sinhalese, Tamil, and English languages. And particularly there are further challenges for UT as Bahasa Indonesia is used as the medium of instruction; whilst lots of OER/MOOCs are available in the English language. It will take a little while for the availability of good translation and transcription software so that OER/MOOCs in the English language can be more readily adopted for Indonesian users. OER and MOOCs take significant time commitment to find the right materials and to design specific online courses for certain clients. Table 17 indicates OUSL and UT challenges in OER and MOOCs in aspects related to awareness and training, integration into teaching and learning, needs for information technology infrastructure and facility, use of English language in most OER and MOOCs, time commitment to making selection of OER and MOOCs, and possible declining trends in enrollments of MOOCs.

\section{Rooms for improvement in OER and MOOCs}

There are common rooms for improvement in OER and MOOCs for both OUSL and UT to consider. Effective implementation of OER and MOOCs begin with policies, so that adoption and wider uses can be effectively implemented. It will a while for new initiatives to be fully understood and effectively implemented, supported with good online connectivity. There are also external aspects for consideration, particularly online connectivity on the parts of the institution and the students. Table 18 indicates those rooms for improvement in aspects related to policies, adoption, and connectivity to ensure effective uses of OER and MOOCs.

\section{Quality assurance}

Quality assurance has become serious attention of stakeholders and educational institutions. Quality assurance in open universities have been implemented referring to standards published by relevant organizations of open and distance education. Many ODL

\begin{tabular}{|c|c|}
\hline Aspects & Common challenges inn OER and MOOCs for OUSL and UT \\
\hline $\begin{array}{l}\text { Awareness and } \\
\text { training }\end{array}$ & $\begin{array}{l}\text { Something newly introduced, need a community of learning support, and encourage } \\
\text { staff to use OER }\end{array}$ \\
\hline Integration & Integrate OER into courses \\
\hline $\begin{array}{l}\text { IT infrastructure } \\
\text { and facility }\end{array}$ & IT infrastructure and online facilities for easy access \\
\hline English language & $\begin{array}{l}\text { English language, and the need for suitable translation into the Sinhalese and Tamil } \\
\text { languages (OUSL); and English language, and the need for translation into Bahasa } \\
\text { Indonesia (UT) }\end{array}$ \\
\hline Time commitment & It takes time to search and find quality OERs to integrate into courses \\
\hline Possible decline & Declining trends in MOOCs \\
\hline
\end{tabular}

Table 17.

Challenges in OER and MOOCs

\section{Aspects Common rooms for improvement in OER and MOOCs for OUSL and UT}

Policies Define and implement clear policies on OER and MOOCs

Adoption Adopt OER and MOOCs that are relevant to student needs

Connectivity Carefully consider technological and online connectivity aspects on the parts of the students
Rooms for improvement in OER and MOOCs 
institutions have adopted the principles of continuous improvement and established a dedicated unit to coordinate implementation of quality assurance system. Mechanisms for quality audits and reviews, internal and external, have been implemented to ensure that their practices meet certain international quality standards and criteria and to secure stakeholders' trust in open and distance education system.

Both OUSL and UT take quality assurance seriously and have implemented quality assurance framework for open and distance education. Quality assurance embraces comprehensive aspects of academic, administrative, and operational activities of open and distance education system. For UT, the large scale of operations to provide services to a large number of students have encouraged UT to adopt the implementation of ISO 9001 and 27001 that are common in business management and information technology industries, as well attention to the academic quality and open and distance education practice. Table 19 below presents findings of OUSL and UT good practices in quality assurance in aspects related to cycle and scope of quality reviews, framework and implementation, quality assurance reference, establishment of unit in charge of quality, quality assessment of academic activities, mechanism of quality assessment, continuous improvement, and quality as value.

\section{Challenges in quality assurance}

QA system has been effectively implemented in both OUSL and UT. There remain challenges to address by OUSL and UT in quality assurance, as quality is a dynamic value

\begin{tabular}{ll}
\hline Aspects & OUSL \\
\hline $\begin{array}{l}\text { Cycle and } \\
\text { scope }\end{array}$ & $\begin{array}{l}\text { A cycle of review every } 5 \text { years, institu } \\
\text { review and program review, involving } \\
\text { external reviewers }\end{array}$ \\
$\begin{array}{l}\text { Framework } \\
\text { and } \\
\text { implementation }\end{array}$ & $\begin{array}{l}\text { Sri Lanka Qualification Framework in } \\
\text { 2017/2018 as reference }\end{array}$
\end{tabular}

UT

implementation

Comprehensive QA system covering academic, administrative, and operational aspects of open and distance education system, involving internal and external reviewers

Internal quality audit and comprehensive external quality reviews every 3 years for ISO 9001 quality management system, ISO 27001 IT security, ANSI data center management; Institution and Study Program Accreditation by the National Board for Higher Education Accreditation; ICDE Quality Reviews

Reference QA Toolkit for ODL system as reference Adoption of AAOU QA Framework and UNESCO/ICDE QA Toolkit as reference

Unit QA unit established with Senior academic in charge recently QA Committee initiated in 2001, then QA Center established since 2003

Assessment Surveys, sessions, guidelines, advices to of academic academics to improve the quality of Academic quality reviews throughout the process of curriculum development, course activities academic programs, with academic quality assurance through peer reviews, feedbacks, training of internal staff

Mechanism Internal quality mechanism, opinions

of assessment from students, lecturers, peer and external reviews

writing, exam paper development involving

cross reviews by senior academics from established universities

Student survey, alumni survey, employer survey, public service survey, staff performance assessment and appraisal, tutor performance evaluation

Continuous Improving the quality of teaching through improvement staff development program Continuous staff development program for Value Quality assurance as shared responsibilities permanent and contract and seasonal staff Quality assurance as shared responsibilities

Table 19. Good practices in quality assurance 
AAOUJ

15,1

30

Table 20.

Common challenges in quality assurance for both OUSL and UT and quality assurance is a creative process. Both institutions emphasize the importance of establishing quality work culture, and quality assurance as vehicle to achieve certain quality criteria and implement continuous improvement. One common issue in many countries including Sri Lanka and Indonesia is the fact that an open university system is generally a sole player in the national higher education system so that accreditation instruments are designed by and quality assessors come mostly from the face-to-face universities with little understanding of the principles and good practices open university system. Table 20 illustrates OUSL ad UT challenges in quality assurance in aspects related to quality review instrument used by external accreditation agency, establishment of quality work culture and value, and the belief in quality audit and review as instrument not as objective.

\section{Rooms for improvement in quality assurance}

As continuous improvement process, there remain rooms for improvement in implementation of a quality assurance system in open and distance education institutions. Quality assurance is a continuous process involving significant commitments in spirit, time, resources, and reference to benchmark and good practices. External benchmarks and reviews are important components of quality assurance, in which external experts and assessors provide feedbacks for continuous improvement of practices for the institutions. Table 21 indicates rooms for improvement in quality assurance in aspects related to continuous improvement of implementation, benchmarking with acknowledged best practices in open and distance education, and enhancement of quality as value, culture, ad ethics.

\section{Views from OUSL regional centers, academic staff, students and alumni} Regional centers

To support student learning OUSL has 9 RC and 19 SC; while UT operates 39 RO plus 1 Center specifically dedicated to providing services to students residing overseas. OUSL SC are developed under the responsibilities of $\mathrm{RC}$ to provide easier access to services by students. Both OUSL RC and UT RO are the points of contacts for students that provide academic and administrative services to students in areas related to academic programs,

\begin{tabular}{ll}
\hline Aspects & Common challenges in quality assurance for both OUSL and UT \\
\hline External quality review & $\begin{array}{l}\text { External quality reviewers originate from campus-based institutions and culture: } \\
1 \text { open university vs 15 conversional universities for in Sri Lanka; and 14,000 } \\
\text { conventional universities in Indonesia }\end{array}$ \\
$\begin{array}{l}\text { Assuring people keep the good spirit for quality assurance adopt quality as } \\
\text { values and culture } \\
\text { Quality audit and review } \\
\text { as tools }\end{array}$ & $\begin{array}{l}\text { Awareness of audits and reviews as tools for improvement not as objective } \\
\text { nor inspection }\end{array}$
\end{tabular}

\section{Aspects}

Continuous improvement Benchmarking

Common rooms for improvement in quality assurance for both OUSL and UT
Quality as value, culture and ethics
Common rooms for improvement in quality assurance for both OUSL and UT

Ensure continuous improvement in implementation of QA system

Benchmark with good practice in other institutions and programs, and refer to QA framework for online learning

Respect and enhance the meaning of quality as value, culture and ethics 
counseling, guidance to find suitable academic programs, administrative support and training for students and tutors.

Academic staff in RCs

Both OUSL and UT employ academic staff in RC or Offices. For OUSL, some academic staff in $\mathrm{RCs}$ express their views that face-to-face sessions are generally more interesting to students than other modes of student support such as online. It is the duty of academic staff to develop students' commitment to learning and monitor their progress. Distance education methods are no easy for students and lecturers alike. Developing the capacities of self-learning is one specific challenge that may be more easily conceptualized than done. In recent times, there are increasing needs for online learning support for students.

For many UT students, face-to-face interactions among peers and with the tutors take place during face-to-face tutorial sessions in tutorial locations. UT students live mostly at a far distance from the ROs. Contacts between UT students and the institution are facilitated to mediated Contact Center, and students are welcome to visit the RO or Head Office if they wish. UT academic staff have supervisory and monitoring functions and assure the quality of services provided to students.

\section{OUSL students' profile}

OUSL students have the advantage of easy access to RCs in terms of time and transportation. Many OUSL students live within the convenient range to visit RC, or students may opt to find accommodation close to RCs to attend learning support services and activities and utilize learning resources available in RCs. Students get the academic support directly from lecturers on any learning matters that they come across during their studies. OUSL students enroll in online courses every year with access to digital learning materials and resources. OUSL applies selection criteria for admissions into its Programs. Students unable to meet admission will have to take Foundation courses in OUSL to be admitted to an OUSL degree program.

\section{Views of OUSL students on learning support}

Learning support for OUSL students cover a broad range of activities that students must follow to get the most benefits of the learning support. Students are engaged in learning through various means of support to engage and motivate them in learning, such as face-to-face sessions, library and online support, student projects, and peer learning activities. There are also increasing interests in online support and the use of OER in OUSL courses. In views of the students, addressing learning needs and activities are important to enrich learning experience through online learning process. The online component of the OUSL course includes downloadable papers and presentations, online assignments, peer learning, development of online learning habits and feedbacks form the lecturers.

\section{Retention of students}

Students acknowledge that there are peers who do not re-register in the following semester, or dropout from the course of program. In the students' views, reasons for dropout include the conditions related to financial reasons; work, family, other commitments; and health and other personal problems. OUSL students also express their views based on experiences of interaction with fellow students of those of conventional face-to-face universities. The students expect to have more activities like the traditional students' such as bootcamps, student exchange program, and face-to-face lectures. A specific issue has been raised as regards to tuition fees charged by OUSL, as conventional universities in Sri Lanka charge no tuition fees.

Supporting students to succeed in ODL 
AAOUJ
15,1

32

Alumni

OUSL alumni express their satisfactions with OUSL academic experience and administrative services, and they have favorable assessment of OUSL as regards to updated learning materials, quality of academics as specialized experts, and positive acknowledgment by employers. OUSL graduates have expectations for students to get benefits from advances in the use of new technologies for open, distance, and online learning. In view of alumni, support for current OUSL students need to enhance the use of technology, online resources, the internet, and practical aspects of student learning. OUSL alumni as professionals and employers have roles in strengthening OUSL programs through feedbacks to Faculty members, involving students in projects and partnerships, contributing to curriculum development to enrich student learning experience, informing academics on recent updates in the workplace, and development of alumni network.

\section{Conclusions}

Findings of this study are expected to improve our understanding of open and distance education in theory and practice, particularly in the areas of student support services that ensure successful learning, based on the experiences of OUSL and UT. These findings are expected to help both OUSL and UT and probably other open universities improve the provision of student support services to facilitate distance learners. Many open universities have been established by the governments in contexts with the specific goals to address challenges confronted in those certain contexts. Yet there are commonalities and differences from which institutions may be able to learn from each other in terms of good practices, challenges, and rooms for future improvements.

Further research is worth exploring, particularly in the area of student support in online learning, in line with recent advances in new technology and the changing needs of students. The new paradigm of integrating online learning into open and distance education is the way forward confronted by open universities. Further in-depth study in this area is inevitable to better understand the theory and improve the practices of open, distance, and online learning. Both open universities share common challenges, particularly in the integration of new technology to enhance learning. There are issues related to how open universities transform into modern open universities integrating new technologies and digitalization to support and enhance distance learning, how their online pedagogies are designed, and how student support services are provided for effective distance learning.

\section{Acknowledgments}

This study has been made possible by the AAOU Inter-University Staff Exchange Fellowship 2019 hosted by The Open University of Sri Lanka that has enabled the authors to spend time for focus group discussions and data collection for one month from July 22 to August 21, 2019. The authors thank the Vice Chancellor of The Open University of Sri Lanka for the Award, and the Rector of Universitas Terbuka Indonesia for the permission to take up the Fellowship. Further thanks go to Senior Administrators, colleagues, and students of both dynamic institutions for warm responses and lively discussions.

\section{References}

Bergquist, W.H. (1992), The Four Cultures of the Academy: Insights and Strategies for Improving Leadership in Collegiate Organizations, Jossey-Bass, San Francisco, CA.

Bergquist, W.H. and Pawlak, K. (2008), Engaging the Six Cultures of the Academy, Jossey Bass, San Francisco, CA.

Berti, M. (2018), "Open educational resources in higher education”, Issues and Trends in Educational Technology, Vol. 6 No. 1, pp. 4-15. 
Blomgren, C. (2018), "OER awareness and use: the affinity between higher education and K-12", International Review of Research in Open and Distributed Learning, Vol. 19 No. 2, pp. 55-70.

Bozkurt, A. and Akbulut, Y. (2019), "Dropout patterns and cultural context in online networked learning spaces”, Open Praxis, Vol. 11 No. 1, pp. 41-54.

Educational Technology (2019), "Definitions of instructional design", available at: https:// educationaltechnology.net/definitions-instructional-design/ (accessed March 18, 2019).

European Commission (2015), Dropout and Completion in Higher Education in Europe, European Commission, Luxembourg.

European Commission/EACEA/Eurydice (2014), Modernisation of Higher Education in Europe: Access, Retention and Employability 2014, Eurydice Report, Publications Office of the European Union, Luxembourg.

Everett, D.R. (2015), “Adding value: online student engagement”, Information Systems Education Journal, Vol. 13 No. 6, pp. 68-76.

Hatzipanagos, S. and Gregson, J. (2015), “The role of open access and open educational resources: a distance learning perspective", The Electronic Journal of e-Learning, Vol. 13 No. 2, pp. 97-105, available at: www.ejel.org

Karunanayaka, S. and Naidu, S. (Eds) (2014), Integrating OER in Educational Practices: Practitioner Stories, The Open University of Sri Lanka, Nawala.

Karunanayaka, S. and Naidu, S. (Eds) (2016), Dreamweaving Open Educational Practices, The Open University of Sri Lanka Nawala, Nugegoda.

Khe, F.H., Chen, Q. and Ying, T. (2018), "Understanding student engagement in large-scale open online courses: a machine learning facilitated analysis of student's reflections in 18 highly rated MOOCs", International Review of Research in Open and Distributed Learning, Vol. 19 No. 3, pp. 69-93.

Kim, D. and Kim, S. (2018), "Sustainable education: analyzing the determinants of university student dropout by nonlinear panel data models”, Sustainability, Vol. 10 No. 954, pp. 1-18.

Kotsiantis, S.B., Pierrakeas, C.J. and Pintelas, P.E. (2003), "Preventing student dropout in distance learning using machine learning techniques”, in Palade, V., Howlett, R.J. and Jain, L.C. (Eds), Lecture Notes in Computer Science, Vol. 2774, Springer-Verlag, Berlin and Heidelberg, pp. 267-274.

Lane, A. and Van Dorp, K.J. (2011), "Open educational resources and widening participation in higher education: innovations and lessons from open universities”, EDULEARN11, The 3rd Anmual International Conference on Education and New Learning Technologies, Barcelona, July 4-5.

Latchem, C. and Jung, I. (2010), Distance and Blended Learning in Asia, Routledge, New York, NY.

Messias, I., Morgado, L. and Barbas, M. (2015), "Students' engagement in distance learning: creating a scenario with lms and social network aggregation”, paper presented to 2015 International Symposium on Computers in Education (SIIE), Setubal, November 25-27.

Miao, F., Mishra, S. and McGreal, R. (Eds) (2016), Open Educational Resources: Policy, Costs and Transformation, UNESCO and COL, Paris and Burnaby.

OECD (2007), Giving Knowledge for Free the Emergence of Open Educational Resources, OECD CERI, Paris.

Park, J.H. and Choi, H.J. (2009), "Factors influencing adult learners' decision to drop out or persist in online learning”, Educational Technology \& Society, Vol. 12 No. 4, pp. 207-217.

Sánchez-Elvira Paniagua, A. and Simpson, O. (2018), "Developing student support for open and distance learning: the EMPOWER project", Journal of Interactive Media in Education, Vol. 1 No. 9, pp. 1-10, available at: https://doi.org/10.5334/jime.470

Senior, R.M., Bartholomew, P., Soor, A., Shepperd, D., Bartholomew, N. and Senior, C. (2018), "The rules of engagement: student engagement and motivation to improve the quality of undergraduate learning", Frontiers in Education, Vol. 3 No. 32, pp. 1-9.

Simpson, O. (2004), "The impact on retention of interventions to support distance learning students", Open Learning, Vol. 19 No. 1, pp. 79-95.

Supporting students to succeed in ODL 
AAOUJ 15,1

Simpson, O. (2008), "Motivating learners in open and distance learning: do we need a new theory of learner support?”, Open Learning, Vol. 23 No. 3, pp. 159-170.

Stiburek, S., Vlk, A. and Švec, V. (2017), "Study of the success and dropout in the higher education policy in Europe and V4 countries", Hungarian Educational Research Journal, Vol. 7 No. 1, pp. 43-56.

Tait, A. (2000), "Planning student support for open and distance learning", Open Learning, Vol. 15 No. 3, pp. 287-299.

Tait, A. (2003), "Reflections on student support in open and distance learning", International Review of Research in Open and Distance Learning, Vol. 4 No. 1, pp. 1-9.

Tait, A. (2014), "From place to virtual space: reconfiguring student support for distance and e-learning in the digital age", Open Praxis, Vol. 6 No. 1, pp. 5-16.

Trowler, V. (2010), Student Engagement Literature Review, The Higher Education Academy, Lancaster University, Lancaster.

UNESCO (2014), Higher Education in Asia: Expanding Out, Expanding Up The Rise of Graduate Education and University Research, UNESCO Institute of Statistics, Montreal.

UNESCO and COL (2015), Guidelines for Open Educational Resources (OER) in Higher Education, UNESCO and COL, Paris and Burnaby.

Wiley, D. (2007), On the Sustainability of Open Educational Resource Initiatives in Higher Education, OECD, Paris.

Willging, P.A. and Johnson, S.D. (2004), "Factors that influence students' decision to dropout of online courses", Journal of Asynchronous Learning Network (JALN), Vol. 8 No. 4, pp. 105-118.

\section{Further reading}

OUSL (2018), “Annual report 2017”, The Open University of Sri Lanka Nawala.

\section{Appendix. List of people consulted at the open university of Sri Lanka}

(1) Prof. S.A. Ariadurai, Vice Chancellor.

(2) Dr Ajith P. Madurapperuma, Deputy Vice Chancellor.

(3) Dr N. Karthikeyan, Senior Lecturer, Physics.

(4) Dr Thushara Priyadarshana, Director of International Unit.

(5) Ms Chandi Perera, Assistant Director of International Unit.

(6) Prof. D.A.R. Dolage, Dean of Engineering Technology, July 24, 2019.

(7) Prof. Shironica P. Karunanayaka, Dean of Education, July 25, 2019.

(8) Dr K.H. Jayawardana, Director of Regional Educational Services, July 26, 2019.

(9) Mr. B.M.P. Somaratna, Director of Operations Division, July 26, 2019.

(10) Dr Sandhya Doluweera, Director of Student Support, July 29, 2019.

(11) Dr Gayathri Jayathilake, Center for Educational Technology \& Media, July 29, 2019.

(12) Dr Geetha Kulasekara, Center for Educational Technology \& Media, July 29, 2019.

(13) OUSL Alumni in Session with OUSL Alumni, July 29, 2019.

(14) Faculty of Engineering Technology, A group of Engineering Technology students, July 30, 2019.

(15) Dr G. Bandarage, Senior Lecturer, Chemistry, July 30, 2019.

(16) Prof. J.C.N. Rajendra, Dean of Sciences, Physics, July 30, 2019. 
(17) Physics students at day school, Physics students, July 31, 2019.

Supporting

(18) Physics Lecturer at day school, Physics Lecturer, July 31, 2019 students to

(19) Ms U.H.B.V.P. Angammana, Assistant Director Colombo RC, August 2, 2019. succeed in

(20) Mr Anushka Bandara, Assistant Director Kandy RC, August 3, 2019.

(22) Academic Staff Members, Kandy RC, August 3, 2019.

(23) Physics Graduate, Kandy RC, August 3, 2019.

(24) Science Students, Kandy RC, August 3, 2019.

(25) Prof. Gaya Ranawaka, Dean of Health Sciences, August 5, 2019.

(26) Dean and Academic Staff, Faculty of Education, August 7, 2019.

(27) Mr Kanthavel, Assistant Director Jaffna RC, August 10, 2019.

(28) A group of Academic Staff, Jaffna RC, August 10, 2019.

(29) A group of students, Jaffna RC, August 10, 2019.

\section{Corresponding author}

Aminudin Zuhairi can be contacted at: aminz@ecampus.ut.ac.id 